\title{
抄錄
}

三好 照：「最新植物照」上卷 本書ノ前版ハ大正八年カラ同九年二至ルマデ士中下ノ三卷 トシテ舅山房カラ出版サレタ场訂改版最新植物學講義デアル。此ノ著ガ植物學ノ一大權威書 トシテ既二定評ノアル事八言ヨ俟タヌ。幾多ノ植物學徒习稗谷スル所ガ多カッタガ、惜シク

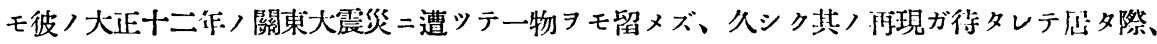

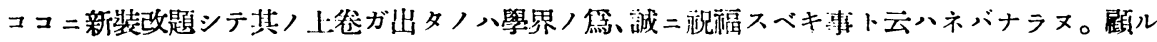
二本書，第一版ガ明治三十二年:仙版サレテ以來、大正九年、デ版ヨ改ムルコト䐴二五包、遂 二今包，第六版即千最新植物學ト銘打ツテ出ルマデ、日本／植物學二携ハル者，誰一人トシテ 本書/厄介ニナラヌ者ガ無イ程、本書ノ存在ト云フモノ八明カデアル。本書八目的八初版以 來植物學全般ノ綜合的知識ノ普及卜云フ事ニアルノデ、今包/改版ニ於テモ前版發行以來十年

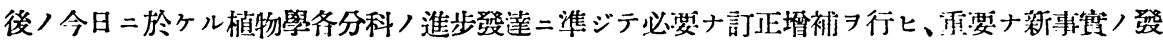
胃ヤ著シイ學說ノ變遷二就テ記述シテアル。

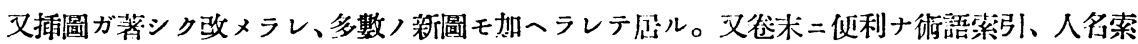
引及ビ各竟/參考書目トヨー括シテ載セテアル。

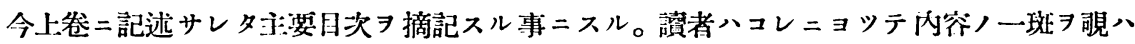
レタイ。

第一音 序 論

第一篇 植物ノ形態及構造:

第二意 䂹花植物 $/$ 形態

第三章 細胞及組織

第四音 隐花植物通說
第二篇 植物豐二於ヶル物椞，代謝

第五章 水/代謝

第六章 日光卜炭素同化们朋

第七章 營 養

第入章 呼吸及發熱

第九章 酵素及酸醋

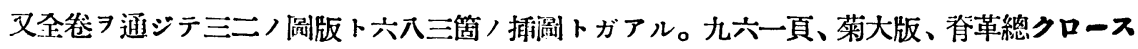
八製本、昭和六年六月十四日發行、定價九圓。發行所八冨山房。过二本書八中然八生理（力

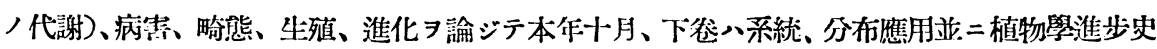
二就テ沭べ、來作一月發行ノ预定デアル。

（本田正次）

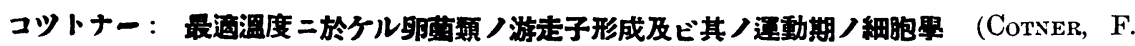

B.: The Development of the Zoöspores in the Oömycetes at Optimum Temperature and the Cytology of their Active Stages. [Amer. Journ. of Bot. 17:511-546 Pls. XXXXXXII, 1930] 材料トシテ八、 Blastocladiales (.17lomyces arbuscula), Saprolegniales (Saprolegnia monoica var. glomerata, Isoachlya paradora, Llchlya conspicuo.) Leptomitales (Apodachlyra bruchynema, Rhipidium europueum), Peronosporales (Phytophythora) 等 7

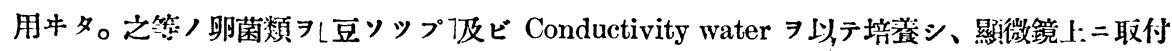




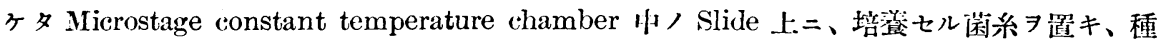
タナル淴度二對シテ、游走子ノ形成及ビ其ノ細胞學的研究ヨ行ツタワヶデアル。一般二游走子.

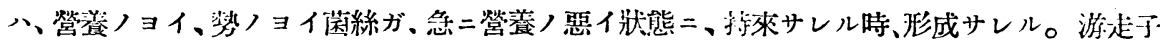
形成，最邀溫度、、種類ニヨッテ连ツテキル。游走子ノ細胞學的䂙究ハ、Crystal violet デ染メ

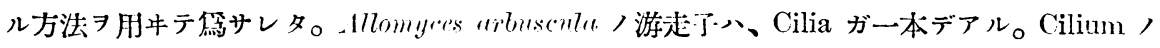

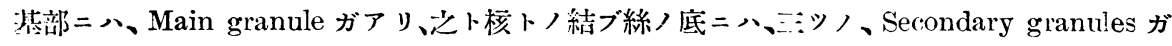
アル。Secondary granules 仯、核小/ Large central chromatic body 二、逨結シティル。

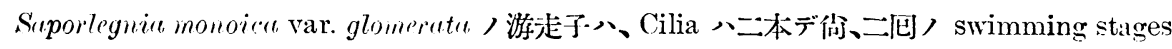
ガアル。最初ノ Swimming stage カラ、Cystノ状態ニ入り、ヤガテCystノ核・三日月形トナ

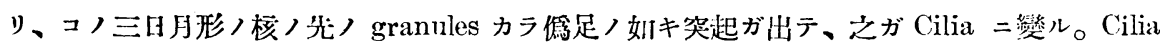

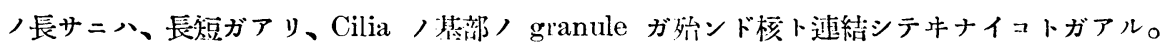
コノ事實ハ、Cilia ノ發有及ビ楎動ヨ支配スルモノ、、コノ granule デハナイカトノ考へヨ

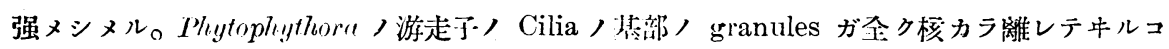

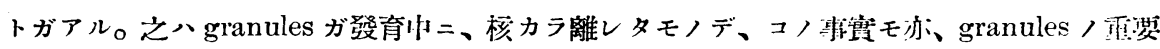
性ヨ示スモノデアル。一般=、Cilia ガ一本ノ種類デ、、Cilium ノ形成ハ、Sporangium 舭 早クカラ大分隻ム。然ル二二本, Cilia ヨ持ッ種類ハ、ソノ形成ガズット掘レ、Zoösporeトナ ル可ク、Sporangium カラ出ル直前二始マルラシイ。二可，Swimming stages $ヨ$ 捇ツ種類デ 八、第一间，Swimming stage／後被膜ヨカブリ、Cyst，就態トナリ、之ガ發芽シテ第二国，

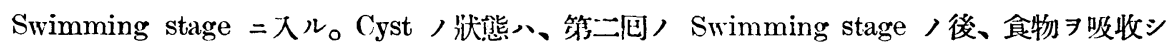
vegetative micelium $\exists$ 作ル樣ニナル䉆ノ Adjustment ガ、核內ニ行ハレル時デアル。Cilia

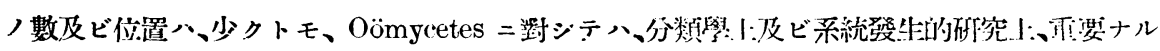
一定形質デアルト考へラレルト。

（湯淺 时）

ヴルク：不等毛類ノ粳毛ノ鹪造二就テ V V LK, W.: Über die Struktur der Heterokonten-

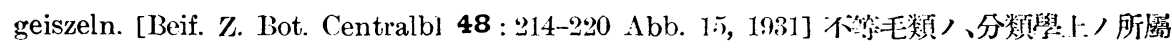

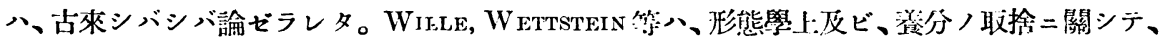

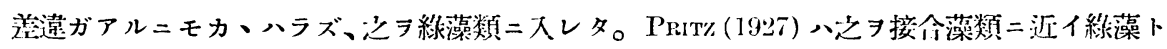

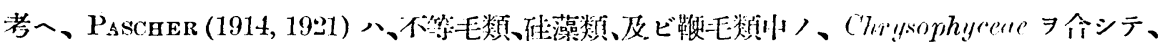

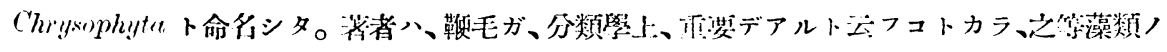

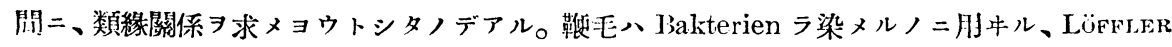

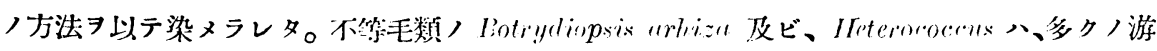

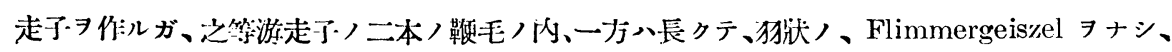
一方八、稍々短クテ、太基部ノ先端ニ細イ Endstiick ヨ掉ッ Peitschengeiszel ヨナス。Flagel-

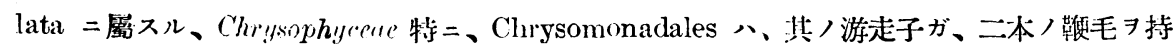
チ、一本八長イ、Flemmergeiszel デアルシ、他ノ一本ハ、稍々浢イ、Peitschengeizei デ、Fnd・ 


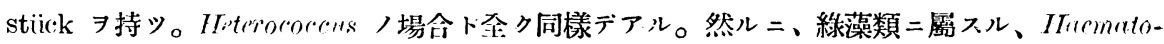

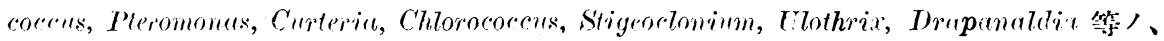

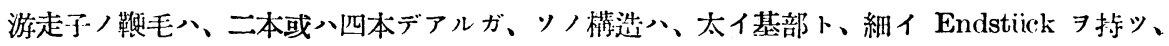
Peitschengeiszel デアル。之等ノ事實カラ蕃者ノ結䜽スル所八、不等毛類、、緑藻類ヨリモ、

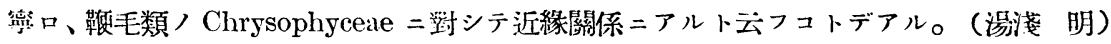

パラトラナ及サントス：でんどろびゆーをノ生活史二關スル頁䖍 Pastrana, M. 1). and Santos, J. K.: $\Lambda$ Contribution on the Life-History of Dendrobium anosmum Lindley. [Univ. of Philippines Nat. and App. Sci. Bull. Vol. 1 pp. 133-143. Pls. 1-111, 1931] 授

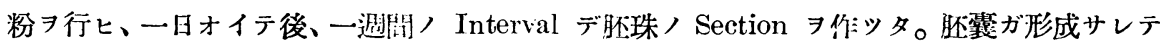
後八、Interval ヨ、二日トシ、受精ノ後、Interval ヨ又一週間トシタ。ソノ量ノ50cc.

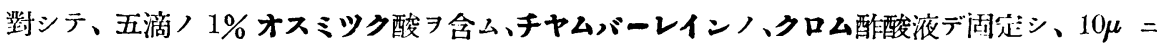
切リ、ハイデンハイン鐵明䄷へマトキシリンデ、染色シタ。受粉後二ヶ月或ハ一ヶ月本デ、受精

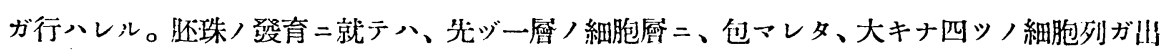
來、コノ列ノ先端ノモノガ、大芽胞母細胞デアル。殘りノ三ッハHaustorium デ、之ハ受精ノ

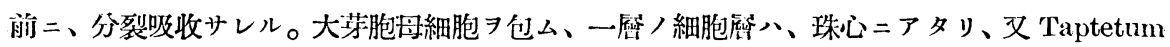
トシテ、後二吸收サレル。珠心ノ底部二、二禹ノ突起ガ出テ、之ハ內外ノ珠皮ヨ形ッ゙クル。

大芽胞母細胞八、異型及ビ同型核分裂ヨ、續ヶテ行ヒ、四ッノ大芽胞 膜ハ形成サレナイ。珠孔二近イオノ三ッハ、退化シ、最後ノーツガ、三四ノ分裂ヨ經テ、构核、

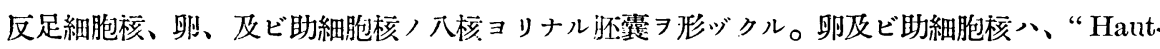
schicht “ニヨツテ、境サレ、文足細胞核二ハ相 7 . $/$ 隔膜ガナイ。重複受精八普通ニ行ハレテ、

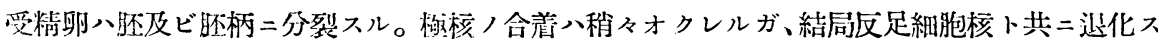

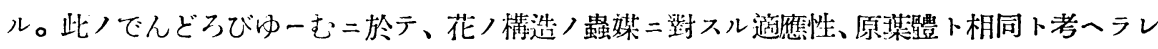
ル反足細胞稌ガ細胞ニカコマレナイコト、还囊形成迄ノ五包ノ核分裂二、細胞板ノ作ラレナイ

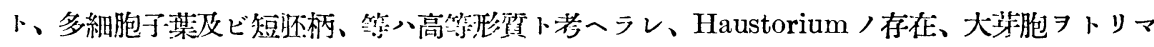
ク一列ノ細胞穈ガ Tapetum ノ役эスルュト四ッノ大芽胞母細胞中三ッノ䢟化スルコト䇰八、 卜等形很ト考へラレル。光等考へルト、コノ植物ハ Primitive type ト Advanced type ト ノ Transitional type デアルト云フ。

(湯浅 明)

ハルトマン： ららぼし科ニ於ケル藏精器ノ張開 HAKTMAN, M. E.： Antheridial Iolis-

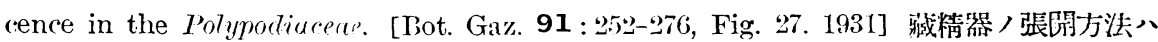

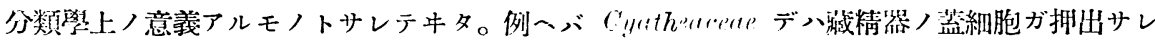

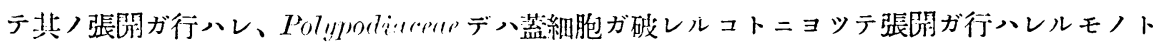

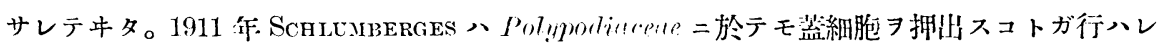

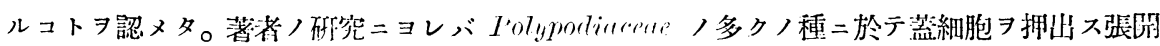
方法ガ見ラレタ。张開ノ姖序ハ、先ヅ精細胞塊ガ漸次膨脹シ藏精器ノ問壁細胞 


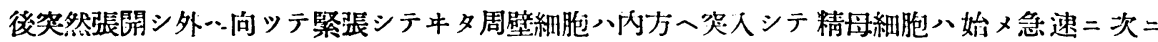

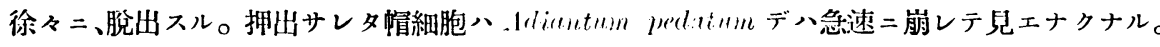

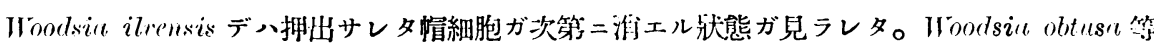

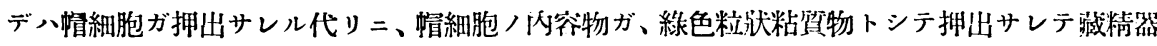

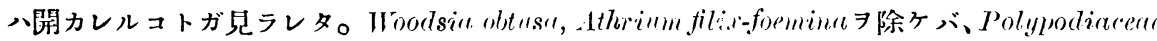

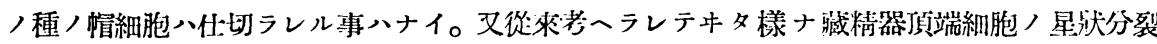

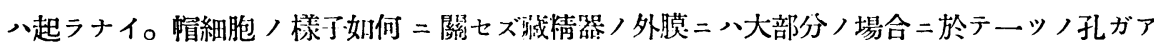

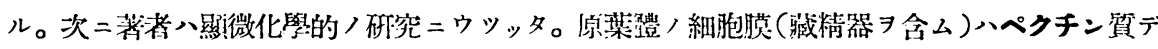
アル。精細胞塊ノ膨張八精細胞膜ノペクチン献カラ内來スル。文膜ノ一部ハセルローズ筫デア

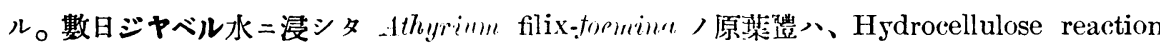
デ Combined cellulose /存在ヨ示ス、蛋白筫及ビ脂肪性ノ物貿モ若イ細胞膜ニハアルラシイ。

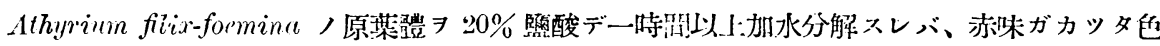
トナル。Orcin, Phloroglucin ハュ/色习强メル。之八加水分解ニヨッテペントーゼガ遊猚ス ルカラデアル。澱粉八精母細胞及ビ精細胞中二兒ラレル。Tannin ガ藏精器/周壁細胞 $=ア$

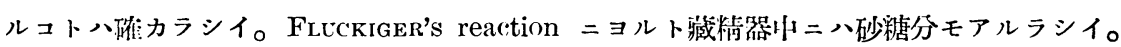

\section{(晹淺 明)}

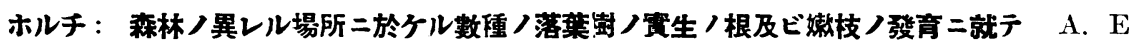

HoLCr : Development of roots and shoots of certain deciduous tree seedlings in dif-

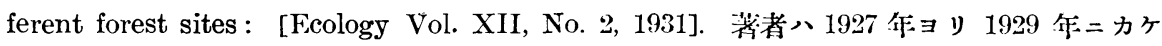

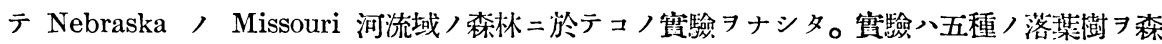
林ノ三ッノ異レル場所二䧄イテッノ賽生 (Seedlings) ニッイテ根及ビ焚枝 (shoots) ノ最初ノ三

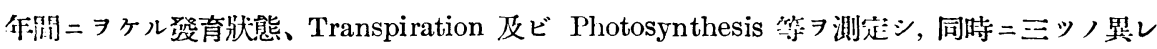

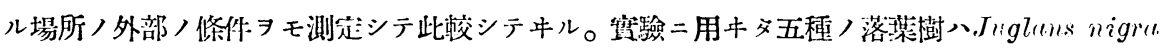
(walnat), Tilin americana (linden), Querrus rubra (red oak), Ificoria orata (hickory), 及

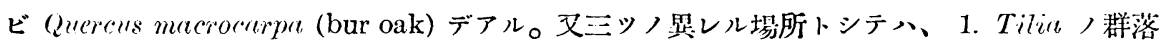
ヨリナル北向キノ急ナ斜愐 (Linden forest)，2. bur oak /群落ヨリナル 酉南问キノュルイ斜 面 (oak forest), 頂ノ一部ガ Prairie grasses デ被ハレテキル小质ノ頂ニ近イュルイ南闹キ，

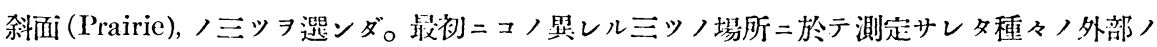
佟件・正此較列舉シテミルト大蹬次ノヤウニナル。

\begin{tabular}{|c|c|c|c|c|c|c|c|c|}
\hline & 土壤 $/ \mathrm{pH}$ & $\begin{array}{l}\text { 壤求分 } \\
\text { 量 }\end{array}$ & 蒸發 & 風速 & 濕度 & 鼠溫 & 蕰歵度 & 光八强サ \\
\hline Prairie & 7.6 & 最小 & 最大 & 最大 & & 鼠高 & 最高 & 最大 \\
\hline Oak forest, & $6.1-6.5$ & 川 & 小 & 山 & & 中 & 小 & 中 \\
\hline Linden forest & $6.2-6.8$ & 裵大 & 㖩小 & 最小 & 大 & 最低 & 最低 & 㻏小 \\
\hline
\end{tabular}

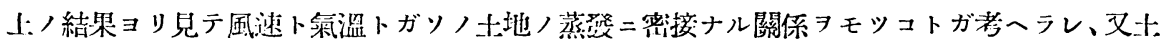




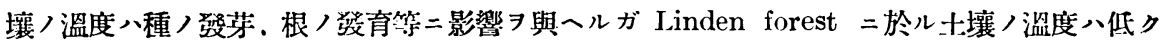
スギテ植物ノ生育二八良イ條件デナイト考へラレルトイフ。们實駗部二近イ Peru ニオケル雨

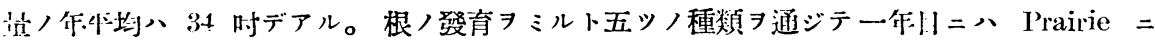

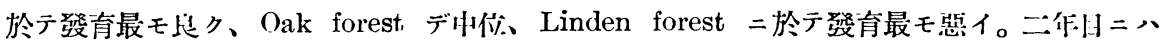
Prairie デハ發育ガ艮クッジケラレ、Oak forest デハヤ、少ッタ發育ヨ亦シ、Linden forest

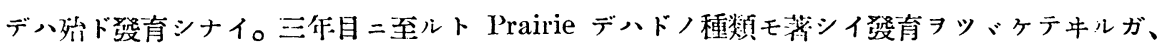
Oak forest デハ walnut ヨ除イタ他ノモノ八發育幊弱デアリ、Linden forest デハTiliaノミガ

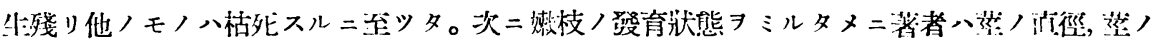

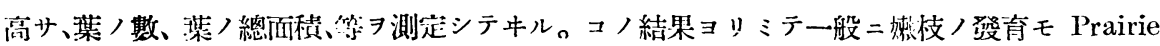
二於テ最モ舆ク、Oak forest デ中位、Linden forest 二於テ最モ惡イトイフ結果ニナッテキ ル。Transpiration ヨ測定シタ結果ハ Prairie 二於テ最大デ、Oak forest デ小位、Linden forest デ最小デアル。Prairie 二於ヶル高イ氣淰ト大ナル風速トガり, Transpiration $ヨ 大$ ナラシムルー因子デアルト考へラレルトイフ。Photosynthesis ‥ SACHS =

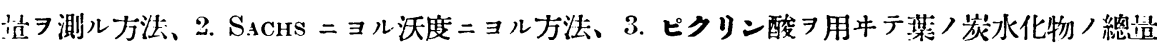

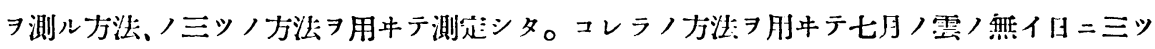

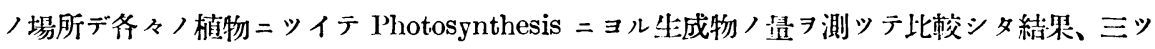

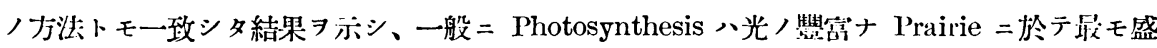
ニ行ハレ Oak forest デ中位デ、暗イ Linden forest デ最モ弱イトイフ結果ヨ得テキル。但シ

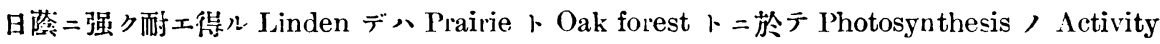

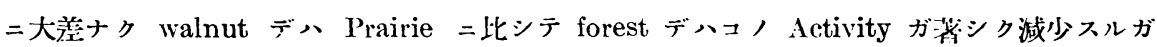
Linden forest ト Oak forest ト䦌二大美ガナイトイフ我苴ヨミティル。コレラ/樹木ノ Seedlings /墢育ハソ/ Photosynthesis / Activity ト采接ナ關係ヨモツモノデアルトイフ コトガ知ラレルトイッテキル。

（津田道夫）

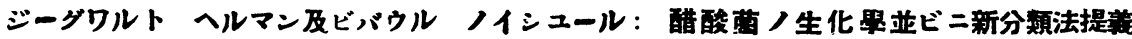

Siegwart Hermani und Paul Neuscirul : Zur Biochemie der Essigbakterien, zurgleich ein Vorschlag für eine neue Systematik. [Biochem. Zeits. 233, 129, 1931.] 醀酸菌十三 種习種々/糖類、アルコール類二働カシメ新シク生ジタ物質ヨ夫タ定性及ビ公湦シタリ。アラ

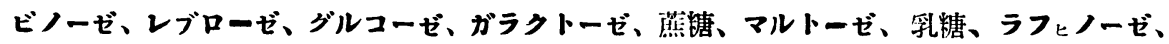
デキストリン、酒精、プロピイルアルコール、ダリセリン、エリスリツト、マンニツト、ソル゙ッ ト、ダルシット、カルシゥムダルコナート及ビダルコン酸/中マルトーゼ、乳糖、デキスト

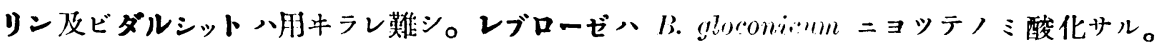

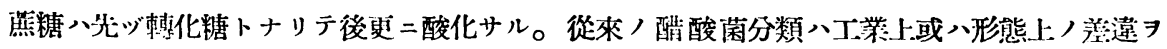
基トシタルモノナリ。化學的性貿ニョッテ醋酸菌ヨ分ッ時明ラカニ Ketogene Bakterien 及 ビ A ketogene Bakterien ノ二種ニナスコトヨ得。前者ハダルコーゼヨ 5-ケトダルコン酸. グ 
リセリンヨヂオキシアセトン、ソルビットヨソルポーゼ、エリスリ、トヨエリスルローゼ =酸

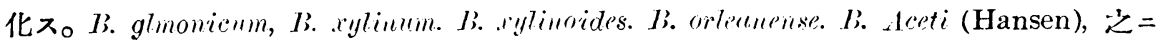

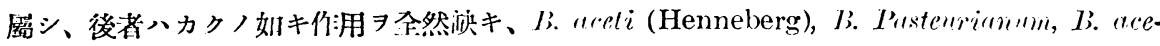

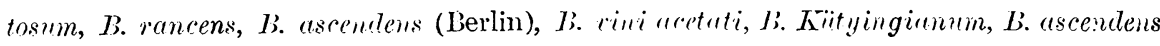

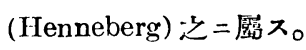

(田中 潔)

コロドニー：損儫、成長、向性二詨テ：CHoLodny. N： verwundung, Wachstum und

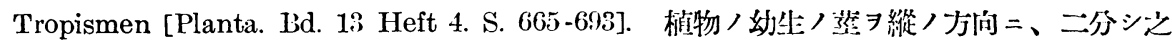

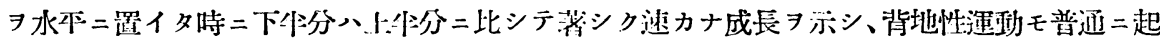

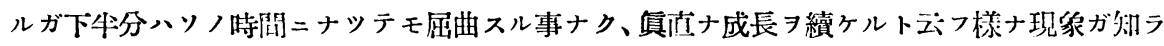

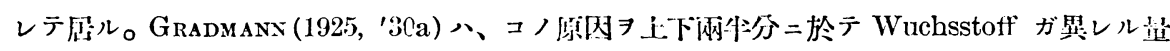

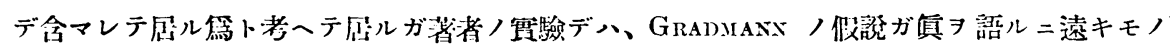

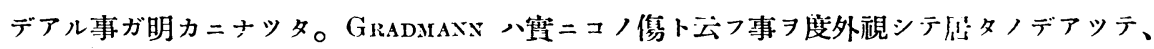

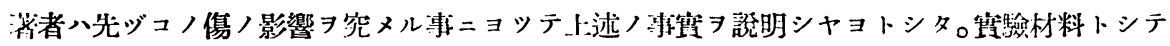

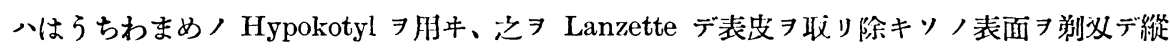

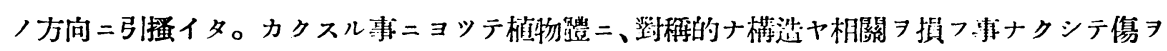

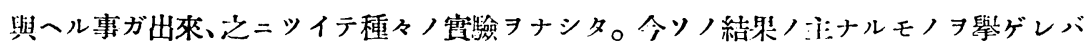

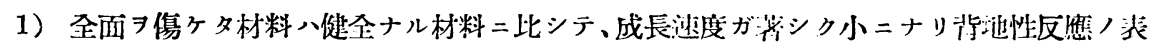
ハレル時間モ著シク後レタ。

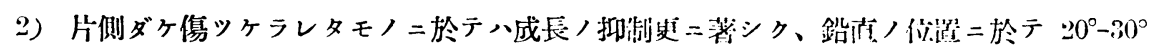
人 Traumatotropisch 人屈曲ガ胃ラレタ。

3）水平ナ位置二於テ傷面

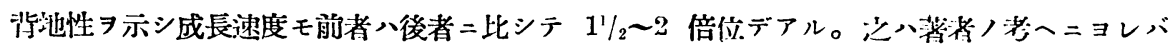
geotrop:smus ト Iraumatotropismus トノ代數的ナ和デ裴ハサレル。

$$
a=g+t, \quad b=g-t
$$

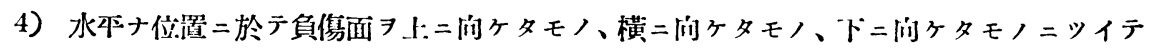

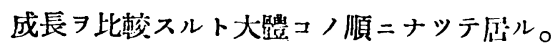

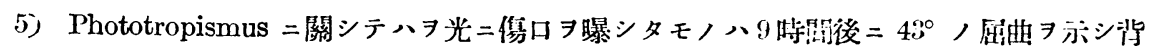

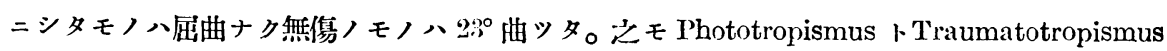
トノ代數的ナ和ノ考へデ證明サレル。

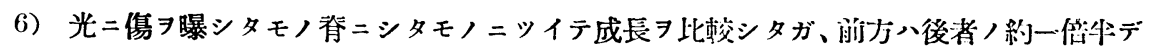
アッタ。

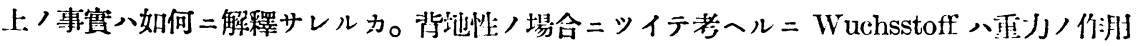
ゲニ下側二集ルコノ際下側ガ健全ナラバ、ソ， Rindeparenchym ガ普通=反㮣スルデアラ ウガ鹪ヨ受ヶテ居ルトキハ正常ナ反想ガ起ラナイ。径テ屈曲成長速度等二美ヨ生ズル。Pho- 
totropismus 二於テモ同樣デ陰ノカニWuchsstoff ガ集ルト云つ事デ說明サレヤウ。

最近電氣生理學ノ發達二伴ツテ、種々/測定ガ行ハレル樟ニナッタガ植物體ノUnterseite 或八Schatterseite ガ電氣的二正二帶電シ、又負傷部八負二帶電スル事ガ知ラレルニ到ツタ。 印于植物體ハ Belichtung, Schwerkraft, Verwundung 管:ニョリ電位差ヨ正ズルノデアッテ ソノ際 Wuchsstoff ガ正ノカニ引キ付ケラレルト云フ考へガ Tropirmus，原团二對スル最新 ノ解釋デ著者ハ之ニョッテTropismus /問題が解泛サレルデアラウト推論シテ居ル。

(小菅潐之助)

\section{學 會 錄 事}

\section{入}

阔山第六高等學校

福岡市外箱崎

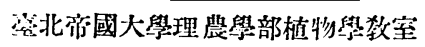

東京标牛达

轉

\section{會}

紹介满

竹还常头近藤武头

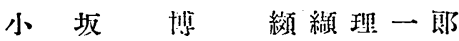

細川隆圤工藤神列

企原八犃常谷幸堆

$\int_{i}^{1}$

上海法祖界沮路一二○號上海自然科學研究所生物经部

兵庫县津多郡係立洲本中學校

梲演市鹤見凅

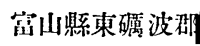

市外中野町

没岛市

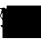
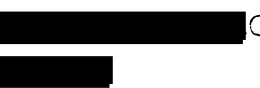

死

饭息相
肥旦趈太郎 松愣亚太即 上鼓㓌 次 御旅屋太作 淺胃具七 弘松磯之助

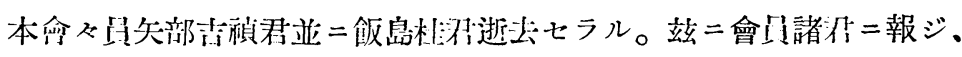

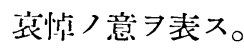

昭和六站八月

束京植物 學 會 


\section{會告}

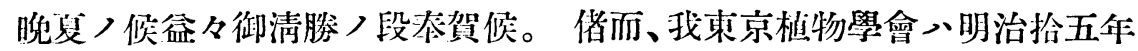

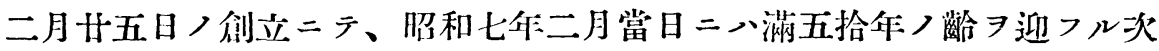
第二候。仍ッテ我學會ハ之二對記念事業 般來二回二互ル有志會门ノ种棪會ノ結果、其事業、施行方法並ビ二日程 等二關シ下ノ通り二內定致シ候間、御諒承御替成ノ上次ノ規定二據り憵

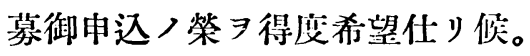

一念事棌亚ビ = 祝賀會次第一

一、眧和七年四月號习援大シ文特别記念號卜ス。但シ內容八會ノ䳸史及學術 論文トス。

詇文申辽楴切昭和六年九月末日。

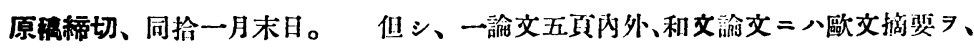
歐交諭交二八和交摘要 $习$ 附スル事。

一、炤和七年四月四日記念會開催。會長ノ挨拶ニ引續キ學術講演會 =移リ、 同五.日モ續行。

購演內容八記念諭交卜同一ニテモ宜シク、講演時間ハ十五分内外。

申込縓切八九月末日/事。

一、同四月四日夜、記念愁親會開催。

一、同四月五日夜、通俗諩演會開催。

請演者八二人内外、內容八通俗 $コ$ 旨トス。

申込楴切八九月末日ノ事。

一、同四月六日、研究所、柾物園等見學ノ豫定。

追而、會場、兄學場所、會費其ノ他未定二就キ、決定次第報告 可仕候。

照和六年八月

東京植物學會 